\title{
DIAGNOSTIC EVALUATION OF CYTOLOGICAL AND HISTOPATHOLOGICAL FINDINGS IN THE DIAGNOSIS OF SOFT TISSUE TUMORS
}

\author{
Aparna Dutta ${ }^{1}$, Pranita Medhi \\ ${ }^{1}$ Assistant Professor, Department of Pathology, Assam Medical College \& Hospital, Dibrugarh, Assam. \\ ${ }^{2}$ Associate Professor, Department of Pathology, Assam Medical College \& Hospital, Dibrugarh, Assam.
}

\section{ABSTRACT}

Soft tissue tumors presents a challenge to the medical professional because of their extremely varied morphology and biologic behaviour. There has been a growing enthusiasm for the aspiration cytology technique in diagnosing soft tissue tumors due to the possibility of providing rapid and adequate pre-treatment diagnosis, the low cost of the procedures and the minimal risk of complications.

\section{OBJECTIVE}

To evaluate the value of FNAC in diagnosis of soft tissue tumors and establish its accuracy by histological correlation.

\section{MATERIALS AND METHODS}

Fifty two cases of soft tissue tumors were aspirated in the Dept. of Pathology, Assam Medical College and Hospital, Dibrugarh. The aspirates were air-dried and wet-smear fixed in 95\% alcohol and stained with MGG and PAP respectively for light microscopic examination. The surgically excised tumors were formalin fixed; paraffin embedded, sections made and stained with $\mathrm{H}$ and $\mathrm{E}$ for histopathological study.

\section{RESULTS}

Out of 52 soft tissue tumors, 37 were benign tumors and 15 malignant ones. In the benign tumors, $89.19 \%$ showed consistent results and $8.11 \%$ showed inconsistent results. In the malignant group, 93.33\% showed consistent results and $6.67 \%$ inconsistent results. There were 14 true positive cases, 33 true negative cases, one false positive case and one false negative case. The overall accuracy of $90.38 \%$ was achieved.

\section{CONCLUSION}

FNAC has significant efficacy in the diagnosis of the soft tissue tumors when combined with detailed history, clinical examination and radiological investigations.

\section{KEYWORDS}

Soft Tissue Tumors, Fine Needle Aspiration Cytology.

HOW TO CITE THIS ARTICLE: Dutta A, Medhi P. Diagnostic evaluation of cytological and histopathological findings in the diagnosis of soft tissue tumors. J. Evolution Med. Dent. Sci. 2016;5(10):402-406, DOI: 10.14260/jemds/2016/93

\section{INTRODUCTION}

With the control of infectious diseases and increased longevity of the growing population, the spectrum of disease changes and the burden of cancer is on the increase. Early diagnosis of cancer has thus become indispensable for cancer control and prevention and the technique of FNAC is becoming a highly creditable diagnostic approach throughout the world.

The technique of fine needle aspiration was first reported by Kun in 1847, but it was Scandinavian Clinician and Pathologist teams who popularized this technique. FNA has proved effective and reliable in the study of primary or metastatic epithelial neoplasms.

Financial or Other, Competing Interest: None.

Submission 19-12-2015, Peer Review 12-01-2016,

Acceptance 21-01-2016, Published 02-02-2016.

Corresponding Author:

Dr. Aparna Dutta,

Assistant Professor,

Department of Pathology,

Assam Medical College \& Hospital,

Dibrugarh-786002, Assam.

E-mail: draparnakamal@gmail.com

DOI: $10.14260 /$ jemds/2016/93
While much success has been achieved with epithelial lesions, there are relatively few reports concerning the advantages and limitations of FNA with soft tissue masses. Soft tissue tumors presents a challenge to the medical professional because of their extremely varied morphology and biologic behavior. In terms of histogenesis and histology, they form a highly heterogeneous group of around 130 lesions, of which $>30$ are sarcomas. While benign tumors are very common, sarcoma are exceedingly rare, accounting $1 \% .[1]$ or less of all malignant tumors in adults. However, they can occur at any age and like carcinomas are more common in older patients, about $15 \%$ affect persons younger than 15 years and $40 \%$ affect persons 55 years or older.[2] Though sarcomas are rare, they are responsible for a large number of cancer deaths, reflecting their lethal nature.

The pathologist plays a major role in the management of soft tissue sarcoma since prognosis depends largely on correct initial diagnosis. FNAC is becoming a valuable tool in the management of soft tissue tumors, since it can effort a diagnostic specificity of $>90 \%$ in the hands of expert pathologist.[3] In 1980s, the aspiration of soft tissue tumors performed at the Medical College of Virginia revealed 95\% sensitivity for the tumor and $98 \%$ specificity for the absence of tumor.[4] 
Akerman and Colleagues estimated that the total reliability of cytodiagnosis in a series of 187 soft tissue tumor is around $85 \%$. They used needles with an outer diameter of 0.7-0.8mm (Gauge-22) and length $50-80 \mathrm{~mm} .{ }^{[5]}$ FNAC in the diagnosis of soft tissue tumor has not been widely accepted due to many reasons, such as potential diagnostic pitfalls, difficulty in determination of the specific tumor type and fearing to implant tumor cells in the needle tract.

On the other hand, there has been a growing enthusiasm for the technique due to the possibility of providing rapid and adequate pretreatment diagnosis, the low cost of the procedures and the minimal risk of complications. Miralles et al. suggested that the cytologic diagnosis on a fine needle aspirate is not a substitute for the histologic diagnosis, but should be regarded as an extremely valuable complement to it.[6] Considering all these aspects, the present study has been undertaken in the cytology section of Department of Pathology, Assam Medical College and Hospital, Dibrugarh, with the aims and objectives to find out the incidence of different soft tissue tumours and correlate FNAC of soft tissue tumours with histopathology wherever available.

\section{MATERIALS AND METHODS}

This is a one-year prospective, hospital-based, cross-sectional study with approval from the Institutional Ethics Committee.

The present study was carried out on 52 patients categorized as soft tissue tumours on FNAC submitted to the Department of Pathology, AMCH, Dibrugarh, for cytopathological and histopathological study. Relevant clinical datas were recorded.

Fine needle aspiration is done after taking aseptic precautions using a $21-G$ needle fitted to a disposable syringe. Aspiration is done by multiple passes in different directions until the material seen in the needle hub. The smears were stained with May-Grunwald Geimsa (MGG) and PAP stain. Histopathology study was correlated with that of FNAC findings. Special stains and immunohistochemistry were done wherever needed.

\section{Inclusion Criteria}

All soft tissue tumours are included without restricting the study to a particular age limit, sex or site of tumour.

\section{Exclusion Criteria}

Recurrent tumours.

Detailed description of the smears were recorded and cytological findings were correlated with subsequent histopathology to find out the diagnostic accuracy rate of FNAC.

\section{RESULTS AND OBSERVATION}

The present series deals with 52 cases of soft tissue tumors, Out of the total of 1024 cases during the one-year study period, subjected to fine needle aspiration cytology in cytology section of Pathology Department, Assam Medical College and Hospital, Dibrugarh. Histopathology was performed in all the cases to establish the diagnostic accuracy of the aspiration cytology and to evaluate the various soft tissue tumours.
The results and observation have been incorporated in the following tables:

In the present series, the 52 soft tissue tumors were classified into two groups:

(i) Benign tumors and (ii) Malignant tumors.

\begin{tabular}{|c|c|c|}
\hline Type of Tumor & Number of Cases & Percentage (\%) \\
\hline Benign & 37 & 71.15 \\
\hline Malignant & 15 & 28.85 \\
\hline Total & 52 & 100 \\
\hline \multicolumn{2}{|c|}{ Table 1: Distribution of benign and malignant soft } \\
tissue tumors \\
\hline
\end{tabular}

\begin{tabular}{|c|c|c|c|}
\hline Age & Male & Female & Total \\
\hline $0-10$ & 3 & 1 & 4 \\
\hline $11-20$ & 4 & 5 & 9 \\
\hline $21-30$ & 8 & 4 & 12 \\
\hline $31-40$ & 10 & 5 & 15 \\
\hline $41-50$ & 4 & 1 & 5 \\
\hline $51-60$ & 4 & 0 & 4 \\
\hline$>60$ & 3 & 0 & 3 \\
\hline Total & 36 & 16 & 52 \\
\hline \multicolumn{4}{|c|}{ Table 2: Showing distribution of age and sex } \\
\hline
\end{tabular}

\begin{tabular}{|c|c|c|c|c|c|c|}
\hline \multirow{2}{*}{ Sex } & \multicolumn{2}{|c|}{ Benign } & \multicolumn{2}{c|}{ Malignant } & \multicolumn{2}{c|}{ Overall } \\
\cline { 2 - 7 } & No. & $\%$ & No. & \% & No. & $\%$ \\
\hline Male & 24 & 64.86 & 12 & 80 & 36 & 69.23 \\
\hline Female & 13 & 35.14 & 3 & 20 & 16 & 30.77 \\
\hline Total & 37 & 100 & 15 & 100 & 52 & 100 \\
\hline \multicolumn{3}{|c|}{ Table 3: Showing Sex distribution of benign and } \\
malignant tumors \\
\hline
\end{tabular}

In the present series, it had been observed that $80 \%$ of malignant tumor occurred in males and compared to only $20 \%$ in females.

\begin{tabular}{|c|c|}
\hline Types of Tumor & No. of Cases \\
\hline Lipoma & 16 \\
\hline Fibrohistiocytic tumors & 6 \\
\hline Haemangioma & 3 \\
\hline Neurilemoma & 3 \\
\hline Fibroma & 3 \\
\hline Fibrolipoma & 2 \\
\hline Neurofibroma & 2 \\
\hline Lymphangioma & 1 \\
\hline Granular cell tumor & 3 \\
\hline \multicolumn{2}{|c|}{ Total } \\
Table 4: Showing distribution of benign soft tissue \\
tumor in order of frequency \\
\hline
\end{tabular}

The most commonly encountered benign tumor was lipoma (43.2\%) followed by benign fibrous histiocytoma (16.21\%), haemangioma (8.1\%), neurilemoma (8.1\%) and fibrolipoma (8.1\%). 


\begin{tabular}{|c|c|}
\hline Malignant Tumor & $\begin{array}{l}\text { Total no. of } \\
\text { Cases }\end{array}$ \\
\hline $\begin{array}{c}\text { Round cell sarcoma } \\
\text { a. Rhabdomyosarcoma } \\
\text { b. Haemangiopericytoma } \\
\text { c. Undifferentiated round cell } \\
\text { sarcoma }\end{array}$ & $\begin{array}{l}3 \\
1 \\
1\end{array}$ \\
\hline $\begin{array}{l}\text { Small round cell tumor } \\
\text { a. Ewing's sarcoma } \\
\text { b. Neuroblastoma }\end{array}$ & $\begin{array}{l}2 \\
2\end{array}$ \\
\hline $\begin{array}{c}\text { Monomorphic sarcoma } \\
\text { a. Malignant fibrous histiocytoma }\end{array}$ & 2 \\
\hline $\begin{array}{c}\text { Malignant spindle cell tumor } \\
\text { a. Fibrosarcoma }\end{array}$ & 1 \\
\hline Well-differentiated Chondrosarcoma & 1 \\
\hline Secondary deposit & 2 \\
\hline Total & 15 \\
\hline
\end{tabular}

Malignant tumors were mainly rhabdomyosarcoma (20\%), neuroblastoma (13.33\%), Ewing's sarcoma (13.33\%) and malignant fibrous histiocytoma $(13.33 \%)$.

\begin{tabular}{|c|c|c|c|}
\hline Tumor Type & $\begin{array}{c}\text { FNAC } \\
\text { diagn } \\
\text { osis }\end{array}$ & $\begin{array}{c}\text { Histopathol } \\
\text { ogical }\end{array}$ & $\begin{array}{c}\text { False } \\
\text { Diagnosis }\end{array}$ \\
\hline Lipoma & 16 & 16 & 0 \\
\hline $\begin{array}{l}\text { Fibro- } \\
\text { histiocytic } \\
\text { tumors }\end{array}$ & 3 & 6 & $\begin{array}{c}3 \text { (2 } \\
\text { inconclusive } \\
\text { diagnosis \& } 1 \\
\text { false positive) }\end{array}$ \\
\hline Haemangioma & 2 & 3 & 1 \\
\hline Neurilemoma & 3 & 3 & 0 \\
\hline Fibroma & 3 & 3 & 0 \\
\hline Fibrolipoma & 2 & 2 & 0 \\
\hline Neurofibroma & 2 & 2 & 0 \\
\hline Lymphangioma & 1 & 1 & 0 \\
\hline $\begin{array}{l}\text { Granular cell } \\
\text { tumor }\end{array}$ & 1 & 1 & 0 \\
\hline \multicolumn{4}{|c|}{$\begin{array}{c}\text { Table 6: Aspiration cytology of benign soft tissue tumor } \\
\text { and its correlation with histopathology }\end{array}$} \\
\hline
\end{tabular}

In diagnosing the benign tumors (37 cases) consistent result with histopathology was found in 33 cases and inconsistent in 4 cases where one resulted in failed aspiration, 2 were diagnostically inconclusive by FNAC and one was with false positive giving $89.19 \%$ diagnostic accuracy.

\begin{tabular}{|c|c|c|}
\hline Case No. & Cytology & Histopathology \\
\hline 27 & Pleomorphic cells with presence of vascular core? Malignant vascular tumour & Benign fibrous histiocytoma \\
\hline \multicolumn{2}{|c|}{ Table 7: Cytology and histology in falsely malignant cytological diagnosis (1 case) } \\
\hline
\end{tabular}

\begin{tabular}{|c|c|c|c|c|}
\hline Tumor type & Cytological Diagnosis & $\begin{array}{l}\text { Histopathological } \\
\text { Diagnosis }\end{array}$ & $\begin{array}{l}\text { True Positive } \\
\text { Diagnosis }\end{array}$ & $\begin{array}{c}\text { False Negative } \\
\text { Diagnosis }\end{array}$ \\
\hline Rhabdomyosarcoma & 2 (Round cell sarcoma) & 3 & 2 & 1 \\
\hline Haemangiopericytoma & 1 & 1 & 1 & 0 \\
\hline $\begin{array}{l}\text { Undifferentiated round cell } \\
\text { sarcoma }\end{array}$ & 2 (Small round cell tumor) & 1 & 1 & 0 \\
\hline Ewing's sarcoma & 2 (Small round cell tumor) & 2 & 2 & 0 \\
\hline Neuroblastoma & 2 (Monomorphic sarcoma) & 2 & 2 & 0 \\
\hline Malignant fibrous histiocytoma & & 2 & 2 & 0 \\
\hline Fibrosarcoma & $\begin{array}{c}1 \text { (Malignant spindle cell } \\
\text { tumor) }\end{array}$ & 1 & 1 & 0 \\
\hline $\begin{array}{l}\text { Well-differentiated } \\
\text { Chondrosarcoma }\end{array}$ & 1 & 1 & 1 & 0 \\
\hline Secondary deposit & 2 & 2 & 2 & 0 \\
\hline Total & 14 & 15 & 14 & 1 \\
\hline
\end{tabular}

\begin{tabular}{|c|c|}
\hline Cytological Diagnosis & Histological Diagnosis \\
\hline $\begin{array}{c}\text { Benign fibrous histiocytic } \\
\text { tumors - (1) }\end{array}$ & Rhabdomyosarcoma \\
\hline Round cell sarcoma-(2) & $\begin{array}{c}\text { Haemangiopericytoma - } \\
\text { (1) } \\
\text { Undifferentiated round cell } \\
\text { sarcoma - (1) }\end{array}$ \\
\hline Monomorphic sarcoma-(2) & $\begin{array}{c}\text { Malignant fibrous } \\
\text { histiocytoma - (2) }\end{array}$ \\
\hline Small round cell tumor -(4) & $\begin{array}{c}\text { Neuroblastoma - (2) } \\
\text { Ewing's sarcoma - (2) }\end{array}$ \\
\hline \multicolumn{2}{|c|}{$\begin{array}{c}\text { Malignant spindle cell } \\
\text { tumor - (1) }\end{array}$} \\
\hline \multicolumn{2}{|c|}{ Table 9: Errors/limitations of cytodiagnosis } \\
\hline
\end{tabular}

Sensitivity - The sensitivity is the ability of a test to identify correctly all those who have the disease.

$$
\begin{aligned}
\text { Sensitivity } & =\frac{\text { True Positive cases }}{\text { True Positive cases + False Negative cases }} \times 100 \% \\
& =\frac{14}{14+1} \times 100 \% \\
& =93.33 \%
\end{aligned}
$$

Specificity - Specificity is the ability of the test to identify correctly, those who does not have the disease.

$$
\begin{aligned}
\text { Sensitivity } & =\frac{\text { True Negative cases }}{\text { True Negative cases + False Positive cases }} \times 100 \% \\
& =\frac{33}{33+1} \text { X } 100 \%=97.06 \%
\end{aligned}
$$

\begin{tabular}{|c|c|c|}
\hline & False Positive (\%) & False Negative (\%) \\
\hline Present study & 2.70 & 6.67 \\
\hline \multicolumn{2}{|c|}{ Table 10: Showing false positive and false negative } \\
results \\
\hline
\end{tabular}


Overall accuracy $=\frac{\text { True Positve Case }+ \text { True Negative cases }}{\text { Total cases }} \times 100 \%$ $=\frac{14+33}{52} \times 100 \%$

$=90.38 \%$

\section{DISCUSSION}

Since the inception of fine needle aspiration more than 50 years ago by Martin and Ellis, 1934, it has travelled to its present popularity over a tortuous road. Fine Needle Aspiration Cytology (FNAC) is well established for evaluation of epithelial tumors for many years. However, only a few published series discuss the FNA cytology of soft tissue tumors and many of these reports contained large number of cases of metastatic carcinoma. Most clinicians dealing with soft tissue lesion are reluctant to accept FNAC diagnosis in determining the treatment modality, chiefly in view of the poor morphological expression in aspirates tumor heterogeneity. ${ }^{[7]}$ focal natures of certain sarcomatous growth. ${ }^{[8]}$ and the limited individual experience of the cytopathologist because of lower incidence of sarcoma. Nevertheless, the cytologic and architectural findings published over the last few years, taken in conjunction with clinical and radiologic data enable cytologic diagnosis to be as precise as those reached through histologic examination in experienced hand.

Aspiration of soft tissue tumors were performed with 22gauge fine needle following the technique of Zajicek et al.[9] Sufficient material was obtained in all cases except 3 cases (5.8\%). Akerman et al.[5] with his experience of aspiration of soft tissue tumor in 1980 and 1985 had reported insufficient material in $5 \%$ and $8 \%$ cases respectively. However, series of $17 \%$ cases with insufficient material had been reported Layfield et al. 1986.[10]

In the present series, 2 cases of haemangioma could not be diagnosed due to the presence of blood in the aspirates. Similar difficulty was also faced by Akerman et al..[5] and Roy et al.[11] in vascular tumors. Cell material mixed with much blood is difficult to interpret, as the cells become packed together and are covered by erythrocytes. In case of extra-skeletal bone tumors and cartilaginous tumors, diagnostic difficulty was faced due to insufficient material and difficult of aspiration with 22-gauge needle. Similar problem was reported by Stormy et al. 1973.[12] Our study included 52 cases (Histologically correlated) of soft tissue tumour were diagnosed (4.84\%) out of total 1076 other neoplasms (95.15\%).

Similar incidence, i.e. 3\% was found by Roy et al. in his series.[11] In the present study, highest number of cases was found between 21-30 years and 31-40 years. In the malignant category age group had gone one step higher, i.e. between 40 60 years of age. According to Enzinger and Weiss.[13] soft tissue sarcoma can occur at any age, but are more common in older patients ( $>50$ years), which is comparable to the present series.

A male preponderance was seen in this series giving the male-to-female ratio of 2.25:1.

The clinical findings and radiologic patterns manifested by soft tissue tumors in the present series were diverse and non-specific. But radiology was of help in one case of chondrosarcoma, two cases of Ewing's Sarcoma and in one case of neurofibroma. Enzinger and Weiss.[13] also stressed on the fact that masses rising in the subcutaneous and deeper soft tissues should be evaluated by radiologic studies, which can detect calcification, ossification or radiolucency within the lesion and can differentiate whether a lesion is primary in soft tissue or primary within bone.

The most common sites of presentation of benign STT were in the extremities, head and neck. In the malignant group, sarcomas were more commonly found in the lower extremity (53.33\%) followed by trunk and chest wall. In the present series, round cell sarcomas were more commonly found on lower extremities, which is comparable to that found by Roy et al.[11]

In the present series, the benign tumors included mostly lipomas (43.2\%) and benign fibrous histiocytomas.

In our study, the overall diagnostic accuracy was found to be $90.38 \%$ (i.e. $47 / 52$ cases). M. Akerman et al.[5] reported the total reliability of FNAC around 85\%; Kulkami et al. in 2002.[14] found overall accuracy in $93.33 \%$ of all soft tissue tumor.

The definite cytologic diagnosis like its histologic counterpart was based on correct evaluation of clinical data, radiologic information and cytologic findings (Architectural pattern, cell and stroma characteristics). The final cytology report placed the tumor in one of the three basic categories: Benign, malignant and inconclusive. The last category included insufficient aspirates. In our study, insufficient material was obtained in 3 cases $(5.8 \%)$.

The aspiration of neural tumors (Neurofibroma and neurilemoma) yielded very scanty material. Aggregates of spindle cells with abundant cytoplasm and elongated nuclei were found in cases of neurofibromas. FNA yielded cohesive spindle-shaped cells with indistinct cytoplasmic boundaries within fibrillary mesenchymal background. The nucleus of the cells were slender and pointed. 'Verocay bodies' could not be demonstrated in neurilemoma in the present study, probably due to lack of cellular aspirates. In the present study, a case of haemangioma revealed only blood cells in aspirates and so could not be diagnosed. Similar difficulties was also faced by M. Akerman et al.[5] Out of total 6 cases of benign fibrous histiocytoma, 2 cases of benign fibrous histiocytoma were misinterpreted due to scanty material. One case revealed only few fibroblast-like cells and fat cells, so misinterpreted to be fibrolipoma. Another case revealed only blood cells and thus rendered to be inconclusive. In our experience, aspirates of $\mathrm{BFH}$ revealed cells with abundant cytoplasm and nucleus having prominent nucleoli and few fibroblast like cells in a haemorrhagic background.

One case of benign granular cell myoblastoma of neck was diagnosed by FNAC as a soft tissue tumors and was later confirmed by histopathology. The smear by MGG stain showed a uniform population of cells with eccentric nuclei and a granular cytoplasm.

Three cases of fibroma was diagnosed cytologically and later confirmed by histopathology. The aspirates of fibroma revealed mostly spindle shaped cells with scant cytoplasm and elongated nucleus in an inflammatory background.

In the sarcoma group, out of total 15 cases one case was misdiagnosed as benign tumor. The case was of a 60 years male with a thigh swelling. The cytology report was inconclusive and thought to be benign fibrohistiocytic tumor. Histopathology diagnosed the case as rhabdomyosarcoma. Thus, in our study false negative was $6.67 \%$ which is comparable to that found by M. Akerman et al. (7\%).[5] and Kulkami et al.[14] 
In our study, out of total 52 cases there were 14 true positive cases, 1 false negative case, 33 true negative cases and 1 false positive case.

Sensitivity of the series is $93.33 \%$ and specificity $97.06 \%$. The overall accuracy rate is $90.38 \%$. These rates compared favorably with the aspiration results from parenchymal organs, such as the breast.[15] and thyroid gland.[16] There is considerable variation in the consistency of benign and malignant tumors. Benign tumors shows a consistency of $89.18 \%$ and malignant tumor shows $93.33 \%$ consistency.

The results and observations made in the present series are compared with other studies as shown in the table.

\begin{tabular}{|c|c|c|c|}
\hline Series & $\begin{array}{c}\text { Sensitivity } \\
\text { (\%) }\end{array}$ & $\begin{array}{c}\text { Specificity } \\
\text { (\%) }\end{array}$ & $\begin{array}{c}\text { Overall } \\
\text { Accuracy } \\
\text { (\%) }\end{array}$ \\
\hline $\begin{array}{c}\text { M. Akerman et } \\
\text { al. (1980) [5] }\end{array}$ & 87.5 & 95.12 & 85 \\
\hline $\begin{array}{c}\text { Frable \& } \\
\text { Frable (1983) } \\
\text { [4] }\end{array}$ & 95 & 98 & 94.3 \\
\hline $\begin{array}{c}\text { Alan CJ et al. } \\
\text { (1985) [17] }\end{array}$ & 89.18 & 95.94 & 89.32 \\
\hline $\begin{array}{c}\text { Layfield et al. } \\
\text { (1986) [10] }\end{array}$ & 95 & 95 & 80.88 \\
\hline $\begin{array}{c}\text { Miralles et al. } \\
\text { (1986)[6] }\end{array}$ & 94 & 96 & 93.2 \\
\hline $\begin{array}{c}\text { Kulkami et al. } \\
\text { (2002)[14] }\end{array}$ & 93.93 & 93.93 & 93.93 \\
\hline $\begin{array}{c}\text { Roy et al. } \\
\text { (2003) [11] }\end{array}$ & 91.4 & 91.4 & 91.4 \\
\hline $\begin{array}{c}\text { Present series } \\
\text { (2003) }\end{array}$ & 93.33 & 93.33 & 93.33 \\
\hline $\begin{array}{c}\text { Showing the percentage of sensitivity, specificity and } \\
\text { overall accuracy in different series }\end{array}$ \\
\hline
\end{tabular}

\begin{tabular}{|c|c|c|}
\hline Author (Year) & $\begin{array}{c}\text { False Positive } \\
\text { (\%) }\end{array}$ & $\begin{array}{c}\text { False Negative } \\
\text { (\%) }\end{array}$ \\
\hline Frable (1983) [4] & 1.21 & 6.96 \\
\hline $\begin{array}{c}\text { Layfield et al. (1986) } \\
\text { [10] }\end{array}$ & 2.00 & 0.09 \\
\hline Allan, CJ et al. (1985)[17] & 6.21 & - \\
\hline Miralles et al. (1986) [6] & 1.17 & - \\
\hline $\begin{array}{c}\text { Bhaskaran et al. } \\
\text { (1988)[18] }\end{array}$ & 2.53 & 6.25 \\
\hline $\begin{array}{c}\text { Kulkami et al. } \\
\text { (2002)[14] }\end{array}$ & 2.08 & 6.67 \\
\hline Present series (2003) & 2.70 & Show the percentage of false positive and false negative \\
\hline \multicolumn{2}{|c|}{ results } \\
\hline
\end{tabular}

In our series, there was one false positive $(2.10 \%)$ and one false negative $(6.67 \%)$ reports as far as malignancy was concerned. These findings are comparable with other studies cited above.

Our experience with FNA cytology of soft tissue tumors indicates that it is a useful and convenient technique for the diagnosis and follow-up of patients with these tumors. Clinical information was an extremely helpful adjunct to cytologic examination and in many cases was necessary for accurate diagnostic interpretation.

\section{REFERENCES}

1. Pollock RE, Karnell LH, Menck HR, et al. The national cancer data base report on soft tissue sarcoma. Cancer, 78:2247-2257, 1996.

2. Jemal A, Siegel R, Ward E, et al. Cancer statistics, 2006; CA Cancer J Clin 2006;56:106-30.

3. Ricardo Gonzalez Campora. Fine needle aspiration cytology of soft tissue tumours. Acta Cytol 44:337-343; 2000.

4. Frable WJ. Thin needle aspiration biopsy. Vol. 14, 319320; 1983.

5. Mans Akerman, Ingrid Idvall and Ander Rydholm. Cytodiagnosis of soft tissue tumours and tumour-like conditions by means of FNAC. Acta Orthop Trauma Surg. 96:61-67; 1980.

6. Miralles TG, et al. FNAC of soft tissue lesions. Acta Cytologica, 30:671-677, 1986.

7. Hajdu SI, Melamed MR. Limitations of aspiration cytology in the diagnosis of primary malignant neoplasms. Acta Cytol 29;337-345, 1984.

8. Ryan M. Cytology and mesenchymal pathology-How far will we go? Am J Clin Pathol 106:561-564, 1996.

9. Zajicek J. Sampling of cells from human tumours by aspiration biopsy for diagnosis and research. Euro J Cancer 1:253, 1965.

10. Layfield LJ, et al. Fine needle aspiration of primary soft tissue lesions. Arch Pathol Lab Med, Vol 110:420-425, 1986.

11. Roy A, Sengupta, et al. Cytodiagnosis of soft tissue lesions. Journal of Cytology. Vol. 20, 2:89-93, 2003.

12. Stormy N, Akerman M. Cytodiagnosis of bone lesions by means of FNAC. Acta Cytol 17:116-173, 1973.

13. Enzinger FM and Weiss SW. Soft tissue tumours. 3rd edition, Mosby, 1995.

14. Kulkarni RD, et al. Fine needle aspiration cytology of soft tissue tumours in correlation with histopathology. Indian J Pathol Microbiol 45(1):45-48, 2002.

15. Kline, et al. FNAC of breast diagnosis and pitfalls. A review of 3,545 cases. Cancer 44:1458-1464, 1975.

16. Stavrie GD, Karanfilski BT, et al. Early diagnosis of clinically non-suspected thyroid neoplasia by the cytologic method. Cancer 45:340-344, 1980.

17. Allan CJ, et al. Osteogenic sarcoma of the somatic soft tissues -clinicopathologic study of 26 cases, cancer 27:1121, 1971.

18. Bhaskaran CS, Sreenivas M. Cytologic study of soft tissue tumour by FNAC. Indian J Pathol Microbiology 31(4):272-279; 1988. 